\title{
ANALISIS CORPORATE GOVERNANCE TERHADAP KINERJA PASAR
}

\author{
Arie Setyo Dwi Purnomo, M Boy Singgih Gitayuda \\ 1,2,Fakultas Ekonomi dan Bisnis Universitas Trunojoyo Madura \\ email: 19arie.dwip@trunojoyo.ac.id, 2Boy.Singgih@trunojoyo.ac.id,
}

\begin{tabular}{l}
\hline Tata Kelola \\
Direksi \\
ROE \\
Tobin Q \\
Kinerja Pasar \\
Diversitas \\
\hline
\end{tabular}

\section{Corporate Governance}

Board of Director

ROE

Tobin $Q$

Market Performance

Diversitas

\begin{tabular}{l}
\hline Arie Setyo Dwi Purnomo dan M Boy \\
Singgih Gitayuda (2020). Analisis \\
Corporate Governance Terhadap \\
Kinerja Pasar. Akuntabilitas: \\
Jurnal Ilmiah Ilmu-Ilmu \\
Ekonomi, 13(1), 21-42
\end{tabular}

\begin{abstract}
ABSTRAK
Penelitian ini bertujuan untuk menguji corporate governance terhadap kinerja pasar di perusahaan perbankan. Sampel dalam penelitian ini adalah perbankan di Bursa Efek Indonesia periode 2011-2019. Hasil penelitian menunjukkan corporate governance berpengaruh positif terhadap kinerja perbankan dengan menggunakan Tobin $Q$ dan return on equity (ROE). Selanjutnya terdapat informasi tambahan dari hasil penelitian ini. Jumlah direksi serta komisaris independen memiliki pengaruh positif. Sedangkan pada keberadaan foreign board director memiliki dampak positef dikarenakan ekpertise yang dimilikinya berbeda dengan direksi lokal. Jumlah kegiatan rapat juga memiliki pengaruh positif terhadap kinerja dikarenakan pasar melihat bahwa kegiatan pengawasan dan pengontrolan kinerja direksi berjalan ssesuai harapan shareholder. Namun keberadaan direksi perempuan dan direksi berpendidikan doktoral berpengaruh negative dikarenakan sosio budaya masyarakat Indonesia masih patriatki dan tingkat tpendidikan tidak selalu memiliki kompetensi dan kemampuan yang dibutuhkan.
\end{abstract}

\section{ABSTRACT}

This study aims to examine corporate governance on market performance in banking companies. The sample in this study is banking in the Indonesia Stock Exchange for the period 2011-2019. The results showed that corporate governance has a positive effect on banking performance by using Tobin $Q$ and return on equity (ROE). Furthermore, there is additional information from the results of this study. The number of directors and independent commissioners has a positive influence. Whereas the presence of foreign board directors has a positive impact because the expertise they have is different from that of local directors. The number of meeting activities also has a positive effect on performance because the market sees that the supervisory and controlling activities of the directors' performance are in line with the expectations of shareholders. However, the existence of female directors and doctoral-educated directors has a negative effect because the socio-cultural aspects of Indonesian society are still patriarchal and the level of education does not always have the competencies and abilities needed

\section{PENDAHULUAN}

Analisis Corporate Governance Terhadap Kinerja Pasar 
Krisis financial yang terjadi sektor institusi keuangan dunia pada tahun 1997 dan 2008. Krisis tersebut juga berdampak kepada Indonesia yang mengakibatkan banyak perusahaan mengalami kebangkrutan. tidak terkecuali perbankan yang diyakini sebagai akibat adanya kegagalan penerapan corporate governance (Kaihatu, 2006). Hal ini membutuhkan penelaah lagi mengenai bentuk investigasi dari corporate governanace yang terjadi pada dunia perbankan. Tata kelola perusahaan yang baik (good corporate governance) telah menjadi isu yang cukup berkembang di Indonesia.

Menurut sebuah kajian yang diselenggarakan oleh Bank Dunia, lemahnya implementasi sistem tata kelola perusahaan atau yang sering disebut dengan istilah corporate governance merupakan salah satu penentu parahnya krisis yang terjadi di Asia Tenggara (Claessens, Djankov, \& Xu, Corporate Performance in the East Asian Financial Crisis, 2000). Kelemahan tersebut terlihat dari minimnya pelaporan kinerja keuangan, kurangnya pengawasan atas aktivitas manajemen oleh dewan komisaris dan auditor, serta kurangnya intensif eksternal untuk mendorong terciptanya efisiensi di perusahaan melalui persaingan yang fair. Lemahnya corporate governance secara umum dianggap berperan penting atas kebangkrutan yang menimpa sejumlah perusahaan besar dan krisis yang terjadi di berbagai negara akhir-akhir ini (Reddy, Locke, \& Scrimgeour, 2010)

Penerapan dan pengelolaan corporate governance yang baik atau yang lebih dikenal dengan good corporate governance merupakan sebuah konsep serta cara yang menekankan pentingnya hak shareholder untuk memperoleh informasi dengan benar, akurat dan tepat waktu. Messier et al (2000) mengungkapkan sistem good corporate governance diperlukan mengawasi dan membimbing manajer dalam berinvestasi dan pengelolahan sumber daya perusahaann. Selain itu juga menunjukkan kewajiban perusahaan untuk mengungkapkan (disclosure) semua informasi kinerja keuangan perusahaan secara akurat, tepat waktu dan transparan. Oleh karena itu, baik perusahaan publik maupun tertutup harus memandang good corporate governance bukan sebagai aksesoris belaka tetapi juga sebagai upaya peningkatan kinerja perbankan (Bhagat \& Bolton, 2009) 
Brigham et al (2007) Return on equity merupakan satu rasio penting dalam pengukuran profitabilitas keuangan perusahaan. ROE mengacu dari total keuntungan bersih perusahaan dibagi dengan jumlah lembar saham yang dipegang investor. Semakin tinggi ROE akan berdampak pada tingginya harga saham. Nilai perusahaan (Corporate value) akan menghasilkan peningkatan profitabilitas bagi shareholder (Husnan 2012)

Corporate governance lebih menfokuskan pada proses dan struktur langsung dalam pengelolahan urusan perusahaan guna meningkatkan nilai para pemegang saham dalam jangka panjang dengan meningkatkan kinerja dan akuntabilitas perusahaan serta memperhitungkan stakeholder lainnya (Jenkinson \& Mayer, 1992). Corporate governance dibutuhkan karena adanya eksistensi dari Theory Agency yang disebabkan dari perbedaan tujuan dari pemilik perusahaan dengan pengelolah perusahaan (Jensen \& Meckling, 1976) Good corporate governance merupakan salah satu mekanisme yang dipergunakan untuk meminimalkan konflik kepentingan antara manajer dan pemilik perusahaan (shareholder).

Pada beberapa hasil penelitian menunjukkan praktek corporate governance yang ada pada perusahaan publik di Indonesia relatif lebih rendah daripada beberapa negara di Asia. Survei (CLSA, 2014) menempatkan Indonesia dan Filipina pada daftar terendah dari 12 negara Asia. Mirip dengan penilaian praktik corporate governance perusahaan public, penilaian di ASEAN tersebut menggunakan ASEAN corporate governance scorecard. Sedangkan survei (ADB, 2014) menunjukkan rata-rata nilai corporate governance perusahaan publik di Indonesia relatif lebih rendah dari rata-rata perusahaan yang berada di Malaysia, Thailand, Filipina dan Singapura.

Pada penelitian (Andres \& Valledado, 2008) menguji corporate governance dengan menggunakan proxy yaitu jumlah direksi, jumlah deposit, umur perusahaan, suku bunga, jumlah pekerja, jumlah branch, dan total kredit di negara Turki. Sedangkan (Adams \& Mehran, Corporate Performance, Board Structure, and Their Determinants in Banking Industry, 2008) menguji hal yang sama namun pada negara yang berbeda. Jauhar 2014 menyatakan bahwa tata kelola perusahaan (proporsi komite audit independen, komisaris independen) 
memberikan dampak signifikan terhadap nilai perusahaan dengan kinerja Tobin Q, MBR dan Closing Price.

Fallatah \& Dickins (2012) pada penelitiannya mengenai pengaruh corporate governance terhadap nilai perusahaan. Indikator corporate governance dimana ukuran direksi, direksi independen, komite audit independen dan kepemilikan saham oleh direksi. Menemukan corporate governance memiliki pengaruh terhadap nilai perusahaan.

Pelaksanaan corporate governance secara efektif, direksi harus terdiri dari individu-individu yang mampu menggabungkan kompetensi dan kemampuan mereka secara kolektif untuk merepresentasi dari kumpulan sosial yang dimiliki perusahaan. Hal ini berkontribusi terhadap pelaksanaan tata kelola perusahaan (Carpenter \& Westphal, 2001)

Dengan demikian, di saat direksi aktif melakukan perannya dalam corporate governance. Maka hasil yang diharapkan merupakan jaminan dari struktur tata kelola yang baik dan tangguh (Zahra \& Pearce, Board of Director and Corporate Financial Performance an Review and Integrative Model, 1989). Namun sejauh mana direksi akan efektif dalam mengemban tugas dan kewajiban, semua tergantung dari faktor eksogen yang lain. Mungkin lebih spesifik terkait faktor gender, pendidikan, dan diversitas direksi.

\section{TINJAUAN PUSTAKA}

\subsection{Jumlah Direksi dan Kinerja}

Ukuran direksi banyak digunakan sebagai indikator baik dalam monitoring dan peran sebagai penasehat (Klein, 1998).Sehingga memainkan peran penting bagi pertumbuhan dan keberhasilan perusahaan. (Beiner, Drobetz, \& Zimmermann, 2003) menegaskan bahwa dewan direktur merupakan struktur perusahaan yang membantu memecahkan permasalahan agensi yang melekat dalam perusahaan publik. Menurut Adrian Cadbury dalam (Cadburry, 1992) dewan direktur bertanggung jawab pada komisaris perusahaan. Dewan direksi memiliki 2 fungsi yakni fungsi penasehat dan pengawasan (Al-Amarneh, 2014) 
Peningkatan profitabilitas akan dapat meningkatkan harga saham perusahaan dan kinerja keuangan perusahaan. (Adams \& Mehran, 2003) menyatakan bahwa jumlah direksi yang cukup besar akan mempermudah pengawasan manajemen yang efektif, sementara besarnya jumlah direksi akan merefleksikan keberagaman pengalaman.

Coles, Daniel \& Naveen (2008) menemukan hubungan positif tobin $\mathrm{q}$ terhadap terhadap jumlah ukuran direksi dalam konteks perusahan yang cukup kompleks. Berdasarkan hal tersebut, dapat dirumuskan hipotesis pertama sebagai berikut:

\section{H1: Jumlah direksi berpengaruh positif terhadap kinerja market value}

\subsection{Komisaris dan Kinerja}

Dalam Peraturan Bank Indonesia No 8/4/PBI/2006 tentang pelaksanaan good corporate governance bagi bank umum, jumlah anggota dewan komisaris diatur paling sedikit 3 orang dan paling banyak sama dengan jumlah anggota direksi dan dipimpin oleh presiden komisaris atau komisaris utama. Sedikitnya 1 orang dewan direksi harus berdomisili di Indonesia. Dalam dewan komisaris terdiri dari komisaris dan komisaris independen. Anggota dewan komisaris harus lulus uji fit and proper test sesuai dengan standar Bank Indonesia dan dewa komisaris independen tidak diperbolehkan memiliki hubungan kekerabatan dengan sesama dewan komisaris ataupun direksi. Komposisi dewan komisaris independen minimal $50 \%$ dari seluruh jumlah dewan komisaris. Dewan komisaris juga diperbolehkan rangka jabatan maksimal 1 sebagai dewan komisaris, dewan eksekutif maupun direksi pada perusahaan lain namun bukan lembaga keuangan.

(Andres \& Valledado, 2008) mengemukakan tentang peranan komisaris sebagai kunci untuk mengawasi perilaku manajer dan untuk memberikan saran dalam hal strategi dan implementasinya. Dewan komisaris yang independen secara umum mempunyai pengawasan yang lebih baik terhadap manajemen, sehingga memengaruhi kemungkinan 
kecurangan dalam menyajikan laporan keuangan yang dilakukan oleh manajer (Chtourous, Bedard, \& Courteau, 2001). Atau dengan kata lain, semakin kompeten dewan komisaris maka semakin mengurangi kemungkinan kecurangan dalam pelaporan keuangan. Dewan komisaris dapat melakukan tugasnya sendiri maupun dengan mendelegasikan kewenangannya pada komite yang bertanggung jawab pada dewan komisaris. Dewan komisaris harus memantau efektifitas pengelolaan korporasi yang baik (good corporate governance) yang diterapkan perseroan bilamana perlu melakukan penyesuaian. Proporsi dewan komisaris harus sedemikian rupa sehingga memungkinkan pengambilan keputusan yang efektif, tepat dan cepat serta dapat bertindak secara independen.

Beberapa penelitian (Drobetz, Schillhofer, \& Zimmermann, 2004), (Bainer, Drobezt, Schimd, \& Zimmermann, 2006), (Bhagat \& Bolton, 2009), Core et al, (2006), dan (Bauer, Braun, \& Clark, 2008)menganalisis mengenai komisaris independen terhadap kinerja perusahaan. Dalam penelitiannya memberikan bukti bahwa ada pengaruh positif antara keberadaan jumlah komisaris independen terhadap kinerja perusahaan

Berdasarkan hal tersebut, peneliti berpendapat bahwa CEO wanita dengan usia yang relatif muda diharapkan memiliki strategi yang lebih tepat dalam pembuatan keputusan perusahaan yang berdampak pada nilai perusahaan. Sehingga dapat dirumuskan hipotesis kedua dan ketiga sebagai berikut:

\section{H2: Jumlah komisaris berpengaruh positif terhadap kinerja market value} H3: Jumlah komisaris independen berpengaruh positif terhadap kinerja market value

\subsection{Board meeting dan kinerja}

Frekuensi rapat komisaris merupakan salah satu faktor dalam mempengaruhi bagaimana aktivitas direksi beroperasi (Vafeas, 1999). Dalam penelitiannya ditemukan hubungan positif antara frekuensi temuan dan kinerja perbankan. Rapat menyediakan tempat bagi para anggota dewan komisaris untuk datang bersama-sama dan mendiskusikan serta bertukar 
pikiran tentang bagaimana mereka memantau manajer dan strategi bank. Semakin sering pertemuan diadakan maka kontrol terhadap manajer semakin ketat dan sangat relevan terhadap fungsi dari pengawasan.

Faktor tersebut akan menyebabkan dampak positif terhadap kinerja perbankan. Kompleksitas bisnis perbankan serta informasi meningkatkan relevansi para pengawas. Sebaliknya pertemuan yang sering juga merupakan mengindikasikan reaksi dewan komisaris terhadap kinerja manajer yang rendah (Andres \& Valledado, 2008)

Berdasarkan hal tersebut, peneliti berpendapat bahwa semakin sering komisaris melakukan rapat maka mengindikasikan reaksi kinerja dewan direksi yang rendah. Sehingga dapat dirumuskan hipotesis keempat sebagai berikut:

\section{H4: Jumlah rapat komisaris berpengaruh negatif terhadap kinerja market value}

\subsection{Majority shareholder dan kinerja}

Kehadiran pemegang saham memegang proporsi yang tinggi pada saham perusahaan merupakan cara lain dalam mengurangi dampak pemisahan antara kepemilikan dan pengawasan dari nilai perusahaan. Pemegang saham dengan kepemilikan yang kecil memiliki insentif yang lemah dalam memonitoring manajer. Para pemegang saham yang kecil akan menyetujui semua biaya keagenan namun mereka mendapatkan sebagian kecil keuntungan (free rider problem) (Belkhir, 2006)

(Bebchuk \& Roe, 1999) menyatakan bahwa struktur kepemilikan dan struktur tata kelola hal yang saling memiliki ketergantungan. Sebuah struktur kepemilikan yang diberikan akan menentukan peraturan perusahaan/pemerintahan untuk alasan efisiensi dan mempertahankan kekuasaan sementara.

Laporan corporate governance dari McKensey, S\&P maupun CLSA menunjukkan bahwa semakin terdispersi kepemilikan saham suatu perusahaan akan mendorong semakin baiknya good corporate governance dalam 
perusahaan. (Claessens, Djankov, \& Lang, The Separation of Ownership and Control in East Asian Corporation, 2000) dan (Fan \& Wong, 2001) membuktikan bahwa kepemilikan yang terkonsentrasi kepada satu pemilik akan menyebabkan praktek corporate governance menjadi buruk. Berdasarkan hal tersebut, peneliti berpendapat keberadaan majority shareholder akan memiliki dampak buruk terhadap corporate governance. Sehingga dapat dirumuskan hipotesis kelima sebagai berikut:

\section{H5: Keberadaan majority shareholder berpengaruh negatif terhadap kinerja market value.}

\subsection{Diversitas dan kinerja}

Struktur direksi merupakan hal penting dalam corporate governance dalam negara berkembang dimana biasanya kontrol pengawasan yang lemah (Claessens \& Yortoglu, 2013). Karenanya ketika direksi menganggap pentingnya sumber daya bagi perusahaan. Keberagaman dimensi mengenai latar belakang dan skill mumpuni merupakan hal penting (Ferreira, 2010).

Salah satu studi tersebut adalah (Kiel \& Nicholson, 2003) bahwa komposisi dewan direksi memiliki dampak positif pada kinerja perusahaan. Keberadaan direksi yang berasal dari luar negeri dapat memengaruhi persepsi mengenai kinerja perusahaan. Keunggulan tersebut sesuai dengan teori ketergantungan sumber daya yang mendapat perhatian serius pada studi corporate governance (Marimuthu \& Kolandaisarny, 2009), (Sridharan \& Marsinko, 1997), (Chen, Patten, \& Roberts, 2008).

Pertama dengan kehadiran jajaran direksi berasal dari luar negeri maka sejumlah besar kandidat berkualitas akan tersedia (dengan pengalaman industri lebih luas). Kedua terkait dengan latar belakang yang berbeda. Anggota direksi tersebut memberikan nilai tambah pada keahlian dan keberagaman yang tidak dimiliki anggota dalam negeri (Chen, Patten, \& Roberts, 2008) Anggota dewan asing juga akan mampu menyakinkan investor minoritas asing bahwa corporate governance dijalankan secara profesional untuk kepentingan mereka (Oxelheim \& Randoy, 2003). 
(Adams \& Ferreira, 2009) menyelidiki mengenai dampak direksi perempuan terhadap kinerja perusahaan di Amerika Serikat. Menemukan bahwa direksi perempuan ternyata lebih banyak mengalokasikan lebih banyak waktu dalam monitoring. Namun rata-rata berpengaruh negatif terhadap kinerja perusahaan. Penelitian lainnya oleh (Carter, Jimkins, \& Simpson, 2003) pada 797 perusahaan dalam versi majalah Fortune 1000. Bahwa perusahaan dengan setidaknya 2 anggota direksi perempuan lebih baik pada aspek pengukuran kinerja menggunakan Tobin $Q$ dan $R O A$ daripada perusahaan yang keseluruhan menggunakan pria. Sedangkan (Kalleberg \& Leicht, 1991) membuktikan tidak ada temuan yang mendukung hubungan antara keberadaan direksi perem[uan dengan kinerja keuangan perusahaan.

Menurut (Ryan \& Haslam, 2005) perempuan cenderung ditempatkan pada pimpinan disaat perusahaan mengalami kemerosotan. Implikasi ini menandakan bahwa kehadiran perempuan dalam jajaran direksi akan dirasakan para pemegang saham bahwa ada perubahan signifikan dalam proses manajemen dan membuat mereka percaya diri akan membawa kesuksesan pada perusahaan yang berakibat pada naiknya harga saham perusahaan.

Sedangkan pada bukti empiris yang menghubungkan kualifikasi pendidikan terhadap direksi terhadap kinerja keuangan perbankan sangat sedikit. (Billimoria \& Piderit, 1994) menguji kualifikasi direksi menggunakan proxy umur,tipe pendidikan, masa jabatan serta pendidikan inklusi dalam tata kelola.

Menurut teori ketergantungan sumber daya. Direksi merupakan aset strategis bagi perusahaan. Dengan demikian kualifikasi pendidikan direksi akan berfungsi sebagai strategi sumber daya perusahaan (Carpenter \& Westphal, 2001). Kualifikasi pendidikan PhD atau doktor akan bertindak sebagai gabungan dari kompetensi dan kemampuan guna membantu fungsi corporate governance dalam perusahaan (Carpenter \& Westphal, 2001). 
Berdasarkan hal tersebut, Bahwa keberadaan direksi sangat dipengaruhi oleh faktor endogen direksi seperti gender, kewarganegaraan, serta pendidikan terakhir. Karena dengan berbagai macam diversitas direksi akan menggambarkan sejauh mana direksi bekerja bagi perusahaan. Sehingga dapat dirumuskan hipotesis keenam, ketujuh dan kedelapan sebagai berikut:

H6: Jumlah foreign board member berpengaruh positif terhadap kinerja market value.

H7: Jumlah direksi perempuan berpengaruh positif terhadap kinerja market value.

H8: Jumlah direksi berpendidikan doktoral berpengaruh positif terhadap kinerja market value.

\section{METODE PENELITIAN}

\section{Data dan Sampel}

Sampel dalam penelitian ini adalah seluruh perusahaan perbankan di Bursa Efek Indonesia (BEI) yang memenuhi persyaratan dalam penelitian ini. Data diperoleh dari website Bursa Efek Indonesia (BEI), Kustodian Sentral Efek Indonesia (KSEI), database Osiris, Bloomberg, dan website perusahaan yang bersangkutan. Akhirnya, terdapat 26 sampel perbankan.

\section{Definisi Operasional}

Penelitian ini merupakan jenis penelitian kuantitatif dengan variabel dependen kinerja perbankan sebagai proxy dari Tobin Q dan ROE, sedangkan variabel dependen ialah jumlah direksi, jumlah komisaris, jumlah komisaris independen, jumlah rapat komisaris per tahun, keberadaan majority shareholder, foreign board member, gender dan kualifikasi pendidikan. Variabel kontrol yang dipergunakan ialah ukuran bank (size). Karena kompleksitas ukuran perusahaan, kemungkinan ukuran dewan direksi meningkat dikarenakan dibutuhkan untuk monitoring dan advice (Pleffer, 1972) dan (Zahra \& Pearce, 1989). 
Tobin's q merupakan rasio dari nilai pasar asset perusahaan yang diukur oleh nilai pasar dari jumlah saham yang beredar dan hutang (enterprise value) terhadap replacement cost dari aktiva perusahaan (Fiakas, 2005)

$$
\text { Tobin } \mathrm{Q}=\frac{\text { MVS }+ \text { Debt }}{\text { Total Asset }}
$$

${ }^{*}$ MVS: Market Value Share

Sedangkan (Adusei, 2011) menguji pengaruh hubungan board structure dan bank performance menggunakan variabel ROE sebagai proxy kinerja perbankan. Berikut ini perhitungan ROE:

$$
\mathrm{ROE}=\frac{\text { Net Income }}{\text { Total Equity }}
$$

Berdasarkan rasio kinerja (variabel dependen) diatas maka dilakukan pengukuran dengan menggunakan corporate governance sebagai variabel independen serta menggunakan varibel kontrol size.

a. Variabel Independen

Dewan direksi merupakan organ dalam perusahaan yang menjalankan sekaligus mengambil keputusan strategis, representasi dari perusahaan dan bagian dari eksekutif atas (Aygun et al, 2001). Ukuran direksi banyak digunakan sebagai indikator baik dalam monitoring dan peran sebagai penasehat (Klein, 1998). Menggunakan jumlah keseluruhan direksi

Dewan komisaris menurut Egon Zehnder dalam Forum for Corporate Governance in Indonesia (2007), dewan komisaris merupakan inti dari corporate governance yang ditugaskan untuk menjamin pelaksanaan strategi perusahaan, mengawasi manajemen dalam mengelola perusahaan serta mewajibkan terlaksananya akuntabilitas. Menggunakan jumlah keseluruhan komisaris.

(Fama \& Jensen, 1983) menyatakan bahwa pengendalian keputusan yang efektif merupakan fungsi positif dari rasio dewan komisari eksternal dengan jumlah total keanggotaan dewan komisaris. Tujuan dari aktivitas 
pengawasan oleh dewan komisaris eksternal adalah untuk memberikan sinyal kepada pasar mengenai reputasi aktivitas pengawasan yang efektif di perusahaan. Menggunakan rasio terhadap keseluruhan komisaris.

Frekuensi rapat merupakan salah satu faktor yang dapat memengaruhi bagaimana aktivitas direksi beroperasi (Vafeas, 1999). Frekuensi rapat menyediakan tempat bagi para anggota dewan komisaris untuk datang bersama-sama dan mendiskusikan serta bertukar pikiran tentang bagaimana mereka memantau manajer dan strategi bank. Semakin sering pertemuan yang diadakan maka kontrol terhadap manajer semakin ketat dan sangat relevan terhadap fungsi pengawasan. Pengukuran menggunakan keseluruhan jumlah rapat dalam satu tahun.

Keberadaan majority shareholder yakni pemegang saham mayoritas yang menjadi pemegang saham pengendali akan mendorong terjadinya expropriate terhadap pemegang saham minoritas. Majority shareholder saham diukur dengan persentase jumlah kepemilikan saham institusi maupun perorangan dalam perusahaan diukur dengan jumlah persentase lebih dari 51\% kepemilikan saham. Jika perusahaan memiliki Majority shareholder maka bernilai satu dan jika tidak memiliki bernilai 0 .

Anggota dewan berkewarganegaraan asing juga akan mampu menyakinkan investor minoritas asing bahwa corporate governance dijalankan secara profesional untuk kepentingan mereka (Oxelheim \& Randoy, 2003). Foreign board member diukur dengan keberadaan jumlah direksi yang berasal dari luar negeri dalam jajaran direksi. diukur dengan komposisi keberadaan jumlah foreign board member dalam jajaran direksi i pada waktu $\mathrm{t}$ serta dibagi dengan jumlah direksi. Menggunakan rasio

Kehadiran dewan direksi perempuan mengindikasikan ada perubahan signifikan bagi perusahaan serta membawa dampak keberhasilan bagi perusahaan (Fondas \& Sassalos, 2000), (Carter, Jimkins, \& Simpson, 2003), (Letendre, 2004) dan (Huse \& Solberg, 2006). Gender diukur dengan komposisi keberadaan jumlah perempuan dalam jajaran direksi i pada waktu t serta dibagi dengan jumlah direksi. Menggunakan rasio. 
Kualifikasi pendidikan doktoral akan berfungsi sebagai aset strategis perusahaan (Carpenter \& Westphal, 2001). Gabungan kompetensi dan kemampuan yang membantu dalam menjalankan fungsi pemerintahan perusahaan (Carpernter \& Westphal. 2001). Komposisi kualifikasi pendidikan diukur dengan keberadaan jumlah direksi yang berpendidikan doktoral perbankan i pada waktu $\mathrm{t}$ dibagi jumlah keseluruhan jumlah direksi. Menggunakan rasio.

b. Variabel Kontrol

Variabel kontrol yang dipergunakan ialah ukuran bank (size). Karena kompleksitas ukuran perusahaan, kemungkinan ukuran dewan direksi meningkat dikarenakan dibutuhkan untuk monitoring dan advice (Pleffer, 1972) dan (Zahra \& Pearce, 1989).

\section{Model Empiris}

Pengujian model empiris untuk menguji hipotesis yang menggunakan proxy kinerja Tobin $\mathrm{Q}$ dan ROE sampai kedelapan hipotesis dilakukan menggunakan analisis regresi dengan model empiris sebagai berikut:

$$
\begin{aligned}
& \text { Tobin } Q_{\mathrm{it}}=\alpha+\beta_{1} D I R_{\mathrm{it}}+\beta_{2} \mathrm{KOM}_{\mathrm{it}}+\beta_{3} \mathrm{KOMID}_{\mathrm{it}}+\beta_{4} M E E T_{\mathrm{it}}+\beta_{5} S H A R E_{i t}+ \\
& \beta_{6} F_{o} B_{i t}+\beta_{7} G E N_{i t}+\beta_{8} E D U C_{i t}+\beta_{9} S I Z E_{i t}+\varepsilon_{\mathrm{i}} \\
& R O E_{i t}=\alpha+\beta_{1} D I R_{i t}+\beta_{2} K O M_{i t}+\beta_{3} K O M I D_{i t}+\beta_{4} M E E T_{i t}+\beta_{5} S H A R E_{i t}+\beta_{6} F_{o} B_{i t} \\
& +\beta_{7} G E N_{\mathrm{it}}+\beta_{8} E D U C_{\mathrm{ii}}+\beta_{9} S I Z E_{\mathrm{it}}+\varepsilon_{\mathrm{i}}
\end{aligned}
$$

\section{Dimana:}

Tobin $Q_{\text {it }}=$ Return on Asset $\mathrm{i}$ pada tahun ke $\mathrm{t}$.

$R O E_{\mathrm{it}}=$ Return on Equity i pada tahun ke $\mathrm{t}$.

$D I R_{\text {it }}=$ Jumlah direksi dari bank i pada tahun $\mathrm{t}$.

$K O M_{i t}=$ Jumlah komisaris dari bank i pada tahun $\mathrm{t}$.

$K O M I D_{\text {it }}=$ Rasio komisaris independen dari bank i pada tahun $\mathrm{t}$.

$\operatorname{MEET}_{I t}=$ Jumlah rapat komisaris dari bank $\mathrm{i}$ pada tahun $\mathrm{t}$.

$S H A R E_{i t}=$ Adanya majority shareholder pada kepemilikan saham dari bank I pada tahun ke t. 1 jika ada dan 0 jika tidak ada (dummy variabel) 
$F o B_{i t}=$ Rasio foreign board member dari bank i pada tahun $\mathrm{t}$.

$G E N_{i t}=$ Rasio direksi perempuan dari bank i pada tahun $\mathrm{t}$.

$E D U C_{i t}=$ Rasio direksi berpendidikan doktoral dari bank i pada tahun $\mathrm{t}$.

$S I Z E_{i t}=$ Log total aset dari bank $\mathrm{i}$ pada tahun ke $\mathrm{t}$.

$\varepsilon_{\mathrm{i}} \quad=$ Faktor error.

\section{PEMBAHASAN}

\section{Hasil Deskripsi Statistik}

Pada deskripsi variabel penelitian akan dijelaskan karakteristik data dengan nilai minimum, maksimum, rata-rata dan standar deviasi. Data yang didapatkan sebannyak 234 pengamatan dengan metode pengambilan data sekunder. Berikut ini data yang telah diolah dengan Eviews 8:

Tabel 1 Deskripsi Statistik

\begin{tabular}{l|c|c|c|c|c}
\hline Variabel & Mean & Median & Minimum & Maksimum & Standar Deviasi \\
\hline TOBIN Q & 1,03 & 1,06 & 0,087 & 4,52 & 0,39 \\
\hline ROE & 9,07 & 9.63 & $-69,9$ & 34,89 & 12,89 \\
\hline DIR & 7,67 & 8 & 3 & 12 & 2,46 \\
\hline KOM & 5,58 & 5 & 2 & 10 & 1,91 \\
\hline KOMID & 0,58 & 0,57 & 0,4 & 1 & 0,10 \\
\hline MEET & 22,8 & 14 & 3 & 74 & 17,75 \\
\hline SHARE & 0,58 & 1 & 0 & 1 & 0,49 \\
\hline FoB & 0,09 & 0 & 0 & 0,6 & 0,13 \\
\hline EDUC & 0,02 & 0 & 0 & 0,5 & 0,07 \\
\hline GENDER & 0,17 & 0,1 & 0 & 0,66 & 0,09 \\
\hline SIZE* & 184 & 89,3 & 2,9 & 1305 & 270,03 \\
\hline
\end{tabular}

*catatan: size (satuan triliun rupiah)

Berdasarkan tabel 1 statistik deskriptif di atas, rata-rata variabel ROE sebesar 9,07\% dan Tobin $Q$ sebesar 1,03\%. Menunjukkan rata-rata berkinerja yang positif. Selanjutnya DIR sebesar 7,67 menunjukkan bahwa jumlah direksi lebih banyak dari ketentuan minimal aturan corporate governance perbankan. KOM atau komisaris memiliki nilai rata-rata sebesar 5,58 lebih tinggi dari minimal persyaratan aturan yakni sebesar 3 komisaris. KOMID atau komisaris independen memiliki rata-rata rasio sebesar 0,58\% yang menggambarkan bahwa keseluruhan perbankan memenuhi persyarat corporate governance komposisi minimal sebesar 50\% dari jumlah komisaris.

Selanjutnya MEET atau rapat komisaris/direksi memiliki rata-rata sebesar 22,8 yang menggambarkan bahwa selama setahun komisaris beserta direksi melakukan 22 kali pertemuan yang melebihi persyaratan aturan corporate governance mewajibkan minimal 4 kali dalam setahun. SHARE atau 
majority shareholder memiliki rata-rata $0,58 \%$ menunjukkan bahwa kepemilikan perbankan dimiliki majority shareholder melebihi ketentuan kepemilikan yang dijadikan standar dari corporate governance.

FoB atau foreign board member memiliki rata-rata $0,11 \%$ yang menunjukkan keberadaan direksi berkewarganegaraan asing disetiap jajaran direksi. EDUC atau kualifikasi pendidikan doktoral direksi rata-rata sebesar 0,02\% mengindikasikan sangat jarang jajaran direksi yang berkualifikasi doktoral. GEN atau keberadaan direksi perempuan sebesar 0,17\% dalam susunan direksi. SIZE atau ukuran aset perbankan memiliki rata-rata 184 trilliun.

\section{Hasil Regresi}

Analisis regresi linier diperlukan dan digunakan untuk mengetahui seberapa besar variabel independen berpengaruh terhadap variabel dependen. Dari hasil pengelolahan model regresi inilah yang nantinya akan dipergunakan sebagai alat analisis penelitian. Hasil dari model regresi yang telah disusun tersebut dapat ditentukan dari nilai koefisien berdasarkan pada hasil perhitungan dengan menggunakan software Eviews 8.

Namun pada penelitian ini dikarenakan alasan variabel keberadaan majority shareholder pada perbankan stabil dari waktu ke waktu maka untuk alasan tersebut model random effect (Tulay \& Kalaycioglu, 2015).

Tabel 2 Hasil Regresi OLS Metode Random Effect

\begin{tabular}{c|c|c|c|c}
\hline \multirow{2}{*}{ Variabel } & \multicolumn{2}{|c|}{ Model Tobin Q } & \multicolumn{2}{c}{ Model ROE } \\
\hline Independen: & $\boldsymbol{\beta}$ & T-Statistik & $\boldsymbol{\beta}$ & T-Statistik \\
\cline { 2 - 5 } Dir & $0,044284^{* * *}$ & 6,135162 & $0,15395^{* *}$ & 2.535741 \\
Kom & 0,010292 & 1,119787 & $-0,191434$ & $-0,243542$ \\
Komid & 1,022623 & 18,39086 & $25,37295^{*}$ & 3.096543 \\
Meet & $0,001156^{*}$ & 1,711661 & 0,097129 & 1,352103 \\
Share & 0,018916 & 0,83129 & $-1,484519$ & $-0,564614$ \\
FoB & $0,235701^{* *}$ & 1,967667 & $-5,483171$ & $-0,753867$ \\
Gender & $-0,240853^{* * *}$ & $-0,365498$ & $-7,005259$ & $-1,1265692$ \\
Educ & $-0,162480^{* * *}$ & $-1,86657$ & 1,627487 & 0,169179 \\
Size & $-1,139484 * *$ & $-2,471148$ & $-0,866232$ & $-1,577598$ \\
\hline
\end{tabular}




\begin{tabular}{c|c|c}
\hline $\boldsymbol{R}$ Square $\left(\boldsymbol{R}^{2}\right)$ & 0,170103 & 0,076173 \\
\hline F-Hitung & $5,101447^{* * * *}$ & $2.052175^{* *}$ \\
\hline $\mathbf{N}$ & 234 & 234 \\
\hline
\end{tabular}

Sumber: Data Sekunder yang Diolah (2017)

*** Signifikan pada tingkat $1 \%$

** $\quad$ Signifikan pada tingkat $5 \%$

* $\quad$ Signifikan pada tingkat $10 \%$

Berdasarkan hasil analisis regresi terhadap 2 model empiris pada tabel 2 diatas ditemukan bahwa jumlah direksi berpengaruh positif terhadap kinerja perbankan. mengindikasikan penambahan direksi memiliki pengaruh signfikan terhadap kinerja pasar bukti tersebut sesuai dengan hipotesis pertama (H1).

Keberadaan komisaris independen pada kinerja ROE memiliki pengaruh signifikan. Namun pada kinerja Tobin-q hanya berpengaruh positif tidak signifikan.

Pada variabel jumlah rapat direksi dan komisaris dalam hasil regresi berpengaruh positif signifikan terhadap kinerja tobin q perbankan. bertolak belakang dengan hipotesis ( $\mathrm{H} 4)$ ini menandakan bahwa fungsi pengawasan yang ada pada komisaris terhadap kinerja direksi sesuai dengan kepentingan shareholder serta miliki korelasi positif signifikan terhadap kinerja pasar.

Variabel independen berikutnya ialah keberadaan majority shareholder ditemukan bahwa keberadaan majority shareholder dengan kepemilikan diatas $51 \%$ berpengaruh positif terhadap kinerja keuangan. Hal ini bertolak belakang dengan hipotesis kelima (H5). Bahwa semakin terdispersi kepemilikan saham perusahaan maka corporate governance semakin efektif serta sesuai dengan teori efficient monitoring hypothesis.

Selanjutnya keberadaan direksi berkewarganegaraan asing atau FoB. Ditemukan bukti bahwa memiliki pengaruh positif signifikan terhadap kinerja tobin q. Bahwa keberadaaan direksi kewarganegaraan asing akan memiliki expertise yang akan berpengaruh terhadap kinerja perbankan.

Pada keberadaan direksi perempuan berpengaruh negative signifikan terhadap kinerja tobin-q. hal ini bertolak belakang dengan hipotesis ketujuh 
(H7). Hal ini kemungkinan berkaitan dengan sisio budaya di Indonesia yang masih patriaki.

Keberadaan direksi dengan pendidikan doktoral berpengaruh negatif. Hal ini bertolak belakang dengan hipotesis peneliti. Bahwa dengan keberadaan direksi doktoral tidak serta merta memiliki kompetensi dan kemampuan sesuai dengan harapan shareholder menggunakan proxy tobin q.

\section{KESIMPULAN}

Corporate governance memiliki pengaruh positif terhadap kinerja perbankan. sehingga sangat penting bagi perbankan untuk mematurhi aturan yang di buat otoritas setempat. Tujuan dari corporate governance ialah mencegah kemungkinan terjadi penyimpangan operasional perbankan dilakukan oleh dewan direksi, komisaris dan pemegang saham pengendali.

Hasil penelitian ini juga memberikan gambaran terhadap berbagai macam karakteristik dari jajaran direksi yang akan mempengaruhi kinerja pasar perbankan. semakin kompleks ukuran perbankan membutuhkan sumber daya dan tata kelola yang advance guna menghindari moral hazard yang terjadi beberapa perusahaan.

Temuan penelitian ini tidak dapat digeneralisasi pada sektor perusahaan lainnya. Dikarenakan hanya fokus pada perbankan. meskipun terdapat kekurangan namun ini akan memperkaya literatur mengenai karakteristik direksi yang berpengaruh terhadap kinerja pasar terutama berkaitan perekonomian emerging market seperti di Indonesia.

Corporate governance memiliki pengaruh positif terhadap kinerja namun dengan kompleksitas dan perbedaan karakteristik bank dengan perusahaan lain. Aturan mengenai jumlah minimal direksi yang sesuai peraturan PBI 8/4/PBI/2006 adalah 3 orang kurang efektif dalam melakukan pengelolahan dan pengawasan terhadap kinerja perbankan. sedangkan aturan PBI 8/4/PBI/2006 bank harus dimiliki blockholder sebesar minimal 20\% kepemilikan saham kurang berimplikasi terhadap kinerja perbankan.

Hasil dalam penelitian ini tidak menggunakan lag t-1 yang akan berguna dalam menggambarkan secara nyata kinerja corporate governance. Dikarenakan 
kemungkinan kinerja perbankan tahun ini dipengaruhi oleh jajaran direksi ditahun lalu. Sehingga diharapkan pada penelitian selanjutnya memasukkan faktor tersebut. 


\section{DAFTAR PUSTAKA}

Adams, R., \& Ferreira, D. (2009). Women in The Boardroom and Their Impact on Governance and Performance. Journal of Finance Economics.

Adams, R., \& Mehran, H. (2003). Is Corporate Governance Different for Bank Holding Company? Economic Policy Review, 123-142.

Adams, R., \& Mehran, H. (2005). Corporate Performance, Board Structure and Its Determinants in The Banking Industry. Working Paper.

Adams, R., \& Mehran, H. (2008). Corporate Performance, Board Structure, and Their Determinants in Banking Industry. Federal Reverse Bank of New York Staff Report, 330.

ADB. (2014). ASEAN Corporate Governance Scorecard: Country Report and Assessment 2013-2014. Asian Development Bank.

Adusei, M. (2011). Board Structure and Bank Performance in Ghana. Journal of Money, Investment and Banking.

Al-Amarneh, A. (2014). Corporate Governance, Ownership Structure and Bank Performance in Jordan. Finance and Banking Department Jordan.

Andres, P. D., \& Valledado, E. (2008). Corporate Governance in Banking: The Role of The Director. Journal Banking of Finance, 2570-2580.

Andres, P. D., Azofra, V., \& Lopez, F. (2005). Corporate Boards in OECD Countries: Size, Composition, Functioning and Effectiveness. Corporate Governance: An International Review.

Bainer, S., Drobezt, W., Schimd, M., \& Zimmermann, H. (2006). An Integrated Framework of Corporate Governance and Firm Valuation. European Financial Management, 249-283.

Bauer, R., Braun, R., \& Clark, G. L. (2008). The Emerging Market for European Corporate Governance: The Relationship Between Governance and Capital Expenditure. Journal of Economic Geography, 441-469.

Bebchuk, L., \& Roe, M. (1999). A Theory Path Dependence in Corporate Ownership and Governance. Stanford Law Review, 127-170.

Beiner, S. W., Drobetz, F. S., \& Zimmermann, H. (2003). Is Board Size An Independent Corporate Governance Mechanism?

Belkhir, M. (2006). Board structure, Ownership structure, and Firm: Evidence from Banking. Document de recherche du LEO.

Bhagat, S., \& Bolton, B. (2009). Governance and Performance. Sarbanes-Oxley (www.law.harvard.edu/confrences/sloan/bhagatSOX.pdf). 
Arie Setyo Dwi Purnomo dan M Boy Singgih Gitayuda / Akuntabilitas 13 (1) 2020, 21-42

Board Committee

Members. Group Organization and Management.

Brigham, J.C., Bennett, L.B., Meissner, C.A. and Mitchell, T.L. (2007), “The influence of race on eyewitness memory", in Lindsay, R.C.L., Ross, D.F., Read, J.D. and Toglia, M.P. (Eds), The Handbook of Eyewitness Psychology, Vol. 2, pp. 257-281

Cadburry. (1992). The Committee on the Financial Aspects of Corporate Governance. Inggris: Cadburry Report.

Carpenter, M. A., \& Westphal, J. D. (2001). The Strategic Context of External Network Ties: Examining The Impact of Director Appoinment on Board Involvement in Strategic Decision Making. Academy of Management, 639.

Carter, D. A., Jimkins, B. J., \& Simpson, W. G. (2003). Corporate Governance, Board Diversity and Firm Value. Eastern Finance Association.

Chen, C., Patten, M. D., \& Roberts, R. W. (2008). Corporate Charitable Contributions a Corporate Social Performance or Legitimacy Strategy. Journal Business Ethnic.

Chtourous, S., Bedard, J., \& Courteau, L. (2001). Corporate Governance and Earning Management. Working Paper.

Claessens, S., \& Yortoglu, B. (2013). Corporate governance in emerging markets: A survey. Emerging Market Review, 1-33.

Claessens, S., Djankov, S., \& Lang, H. (2000). The Separation of Ownership and Control in East Asian Corporation. Journal of Financial Economics, 81-112.

Claessens, S., Djankov, S., \& Xu, L. C. (2000). Corporate Performance in the East Asian Financial Crisis. The World Bank Research Observe.

CLSA. (2014). Corporate Governance in Asia. www.csla.com.

Coles, J. L., N. D. Daniel and L. Naveen (2008). 'Boards: does one size fit all?', Journal of Financial Economics, 87, pp. 329-356

Drobetz, W., Schillhofer, A., \& Zimmermann, h. (2004). Corporate Governance and Expected Stock Return: Evidence from Germany. European Financial Management, 267-293.

Erhardt, N., Werbel, J., \& Shrader, C. (2003). Board of Director Diversity and Firm Financial Performance. Corporate Governance: An International Review , Vol. 11, No. 2, pp. 102-111.

Fama, E. F., \& Jensen, M. (1983). Separation of Ownership and Control. Journal of Law and Economics, 301-325.

Fan, J., \& Wong, T. (2001). Corporate Ownership Structure and the Informativeness of Accounting Earnings in East Asia. CEI Working Paper.

Ferreira, D. (2010). Board Diversity. Journal of Finance Economics. 
Fondas, N., \& Sassalos, S. (2000). A Different Voice in The Boardroom: How The Presence of Women Direction Affects Board Influence Over Management. Global Focus.

Ghozali, I. (2009). Ekonometrika. Teori, Konsep, dan Aplikasi dengan SPSS 17. Semarang: Badan Penerbit Universitas Diponegoro.

Huse, M., \& Solberg, A. G. (2006). Gender Related Boardroom Dynamics: How Scandinavian Women Make and Can Make Contribution on Corporate Board. Women in Management.

Husnan, S. (2012), Manajemen Keuangan Teori dan Penerapan (Keputusan Jangka Panjang), Edisi 4., BPFE, Yogyakarta

Indonesia, B. (2000). Sejarah Bank Indonesia: Perbankan 1997-1998. Unit Khusus Museum Bank Indonesia: Sejarah Bank Indonesia , 1.

Jenkinson, T., \& Mayer, C. (1992). The Assessment: Corporate Governance and Corporate Control. Oxford Review of Economic Policy, vol. 8, issue 3, 1-10.

Jensen, C. M., \& Meckling, H. W. (1976). Theory of The Firm: Managerial Behavior, Agency Cost and Ownership Structure. Journal Financial of Economics, 831-880.

Kaihatu. (2006). Good Corporate Governance dan Penerapannya di Indonesia. Jurnal Manajemen dan Kewirausahaan.

Kalleberg, A. L., \& Leicht, K. T. (1991). Gender and Organizational Performance: Determinants of Small Business Survival and Success. The Academy of Management Journal.

Kiel, G., \& Nicholson, G. (2003). Board Composition and Corporate Performance: How the Australian Experience Informs Contrasting Theories of Corporate Governance. Corporate Governance an International Review, 189-205.

King, R. G. (1993). Finance and Growth: Schumpeter Might be Right. Quarterly Journal of Economics, 717-37.

Klein, A. (1998). Firm Performance and Board Committee Structure. Journal Law and Economics, 137-165.

Letendre, L. (2004). The Dynamics of The Boardroom . Academy of Management Executive.

Levi, M., Li, K., \& Zhang, F. (2014). Director Gender and Mergers and Acquisitions. Journal of Corporate Finance, 185-200.

Liu, Y., Wei, Z., \& Xie, F. (2014). Do Women Directors Improve Firm Performance in China. Journal of Corporate Finance, 169-184.

Luckerath-Rovers, M. (2011). Women on Board and Firm Performance. Journal of Management and Governance, Vol. 17, No. 2, pp. 491-509. 
Lynn, R., \& Irwing, P. (2004). Sex Differences on the Progressive Matrices: A Meta Analysis. Intelligence, 32(5), pp: 481-498.

Marimuthu, M., \& Kolandaisarny, I. (2009). Ethnic and Gender Diversity in Boards of Directors and Their Relevance to Financial Performance of Malaysian Companies. Journal of Sustainable Development.

Messier, S.P., Loeser, R.F., Mitchell, M.N., Valle, G., Morgan, T., Rejeski, W.J. and Ettinger, W.H. (2000)," Exercise and weight loss in obese older adults with knee osteoarthritis: a preliminary study" ,Journal of the American Geriatrics Society, Vol. 48 No. 9, pp. 1062-1072

Meyerinck, F. V., Oesch, D., \& Schmid, M. (2016). Is Director Industry Experience Valuable? Financial Management, pp. 207-237.

Oxelheim, H. L., \& Randoy, T. (2003). The Impact of Foreign Membership on Firm Value. Journal of Banking and Finance.

Pleffer, J. (1972). Size and Composition of Corporate Boards of Directors: The Organization and Its Enviroment. Admininistrative Science Quaterly.

Polanyi, M. (1966). The Tacit Dimension. New York: Doubleday: Garden City.

Reddy, K., Locke, K., \& Scrimgeour, F. (2010). The Effieciency of Principle Based Corporate Governance Practices and Firm Financial Performance: An Empirical Investigation. International Journal of Managerial Financce, 190-219.

Rose, C. (2007). Does Female Board Representation Influence Firm Performance? The Danish Evidence. Corporate Governance: An International Review, Vol. 15, No. 2, pp. 404-413.

Ryan, M. K., \& Haslam, A. (2005). The Glass Cliff: Evidence That Women are Over Represented in Precarious Leadership Positions. British Journal of Management.

Sridharan, U. V., \& Marsinko, A. (1997). Ceo Duality in The Paper and Forest Product Industry. Journal of Finance and Strategic Decision.

Tandelilin, E., Kaaro, H., Mahadwartha, P., \& Supriyatna. (2007). Corporate Governance, Risk Management, and Bank Performance : Does Type Ownership is Matter? EADN WORKING PAPER No. 34, 1.

Tulay, I. N., \& Kalaycioglu, O. (2015). The effects of the Board Composition, Board Size and CEO Duality on Export Performance: Evidence From Turkey. Management Research Review.

Vafeas, N. (1999). Board Meeting Frequency and Firm Performance. Journal of Finance Economics, 113

Zahra, S. A., \& Pearce, J. A. (1989). Board of Director and Corporate Financial Performance an Review and Integrative Model. Journal of Management, 291-334. 